\title{
LHX6 Affects Erlotinib Resistance and Migration of EGFR-Mutant Non-Small-Cell Lung Cancer HCC827 Cells Through Suppressing Wnt/ $/$-Catenin Signaling [Corrigendum]
}

\author{
Wang Q, Liao J, He Z, et al. Onco Targets Ther. \\ 2020;13:10983-10994
}

On page 10993, Funding section, "This study was supported by grants from the Natural Science Foundation of Fujian Province (grant nos. 2017J01261 and 2016JD1488)" should have been "This study was supported by grants from the Natural Science Foundation of Fujian Province (grant nos. 2017J01261 and 2016J01488)”.

The authors apologize for this error.

\section{Publish your work in this journal}

OncoTargets and Therapy is an international, peer-reviewed, open access journal focusing on the pathological basis of all cancers, potential targets for therapy and treatment protocols employed to improve the management of cancer patients. The journal also focuses on the impact of management programs and new therapeutic agents and protocols on patient perspectives such as quality of life, adherence and satisfaction. The manuscript management system is completely online and includes a very quick and fair peer-review system, which is all easy to use. Visit http://www.dovepress.com/ testimonials.php to read real quotes from published authors. 